\title{
MEDICAL AND ECOLOGICAL RISKS OF URBAN AGGLOMERATIONS
}

\author{
Natalia V. Yudina, Ekaterina P. Lysova, Alla V. Koroleva \\ Don state technical university. Rostov-on-Don, Russian Federation \\ science-almanac@mail.ru
}

The modern demographic and social processes of urbanization lead to intensive development of new planning and territorial structures, urban agglomerations. Today, the agglomeration is viewed as an integral socio-economic space with a common system of transport and engineering services, a single natural and ecological framework of the territory. The stability of such urban ecosystems can be assessed through the comfort of life and health of the population, based on groups of criteria: naturalanthropogenic, social, medico-ecological. The analysis of forming ecological carcass of Rostov agglomeration educed potential conflict between development of big city and emphasizing of specially-protected areas (nature reserve "Levoberezhny") in its boundary. Thus, under the density increase of migratory birds on the territories of the nature reserve in the suburbs, the probability of outbreak risk increase of such diseases, as Francis disease, Crimean-Congo hemorrhagic fever (CCHF) and West Nile encephalitis (WNE) is growing. The contact of migrants with established synanthropic urban populations can lead to carry and seasonal rooting of arbovirus infections. The safety and comfort of living in urban agglomerations with territorially close specially protected natural areas directly depends on monitoring the species diversity and the number of epidemiologically significant faunal components as potential carriers and vectors of the causative agents of zoonotic infections.

Key words: urban agglomerations, specially protected natural sites (SPNS), ecological carcass of the territory, medico-ecological risks, habitation comfort. \section{мераций] \\ [Юдина Н.В., Лысова Е.П., Королева А.В. Медико-экологические риски городских агло- \\ Современные демографические и социальные процессы урбанизации приводят к интенсив-} ному развитию новых планировочно-территориальных структур, городских агломераций. Сегодня, агломерация рассматривается как целостное социально-экономическое пространство с общей системой транспортного и инженерного обслуживания, единым природно-экологическим каркасом территории. Устойчивость таких урбоэкосистем можно оценивать черезкомфортность жизни и здоровья населения, основанную на группах критериев: природно-антропогенных, социальных, медико-экологических. Анализ формирующегося экологического каркаса Ростовской агломерации выявил потенциальную конфликтность между развитием крупного города и выделением особоохраняемых территорий (заказник «Левобережный») в его черте. Так при увеличении плотности пролетных птиц на территориях заказника в окрестностях города повышается вероятность увеличения риска вспышек очагов таких заболеваний, как туляремия, Крымская геморрагическая лихорадка (КГЛ) и лихорадка Западного Нила (ЛЗН). Контакт мигрантов со сложившимися синантропными городскими популяциями может привести к заносу и сезонному укоренению арбовирусных инфекций\%. Безопасность и комфортность проживания в городских агломерациях с территориально близкими особо охраняемыми природными территориями напрямую зависит от мониторинга видового разнообразия и численности эпидемиологически значимых фаунистических компонентов как потенциальных носителей и переносчиков возбудителей зоонозных инфекций.

Ключевые слова: городская агломерация, особо-охраняемые природные территории (ООПТ), экологический каркас территории, медико-экологические риски, комфортность проживания.

Natalia V. Yudina - candidate of Biology, associate professor. Academy of construction and architecture. Don state technical university. Rostov-on-Don, Russian Federation.

Ekaterina P. Lysova - candidate of technical sciences, senior lecturer. Academy of construction and architecture. Don state technical university. Rostov-on-Don, Russian Federation.

Alla V. Koroleva - senior lecturer. Academy of construction and architecture. Don state technical university. Rostov-on-Don, Russian Federation. 
ЮдинаНатальяВладимировна - кандидатбиологическихнаук, доцент. Академия строительства и архитектуры. Донской государственный технический университет. г. Ростов-на-Дону, Россия. Лысова Екатерина Петровна - кандидат технических наук, старший преподаватель. Академия строительства и архитектуры. Донской государственный технический университет. 2. Ростов-на-Дону, Россия.

Королева Алла Викторовна - старший преподаватель. Академия строительства и архитектуры. Донской государственный технический университет. г. Ростов-на-Дону, Россия.

Modern agglomerations and megapolises are key centers for the development of the global economy.Today, mainly the large cities acts everywhere as centers for the social and economic development of the territories in Russia.Sustainable development of agglomeration is connected with the construction of a natural - ecological framework of the territory as a priority task of spatial organization for improving life comfort of the urban population.Medico-ecological index can be chosen as one of the integral indicators of the surrounding urban environment state.Specially-protected natural areas (SPNA) in the structure of any agglomeration can be considered as a part of ecological territory carcass and a factor of the region ecological stability. 9,8\% from the general part of the land falls within SPNSon the territory of The Russian Federation, in the South federal district about $10,6 \%$.The Rostov agglomeration located in the south of the European part of Russia has a unique geopolitical and geo-economic position and is a monocentric structure with a nuclear center in Rostov-on-Don and a population of more than 2 million people.

SPNA on the territory of Rostov agglomeration act as centers (nucleus) of the territory ecological carcass, consider to be reservations of territories biodiversity and influence the squares from 100 to 1000 thousand $\mathrm{km}^{2}$. The general square of SPNA of the Rostov region comprises 222,54 thousand ha or $2,2 \%$ from the general territory. The list of SPNA of the Rostov region on 01.01.2016 includes:

1. Federal significance:State natural biosphere reserve "Rostov" - 9,465 thousand ha (Orlovskyregions); trict).

2. The state nature reserve "Tsimlyansky" - 44.998 thousand ha (Tsimlyansky dis-

3. Regional significance: Nature Park "Donskoy" - 40.96 thousand ha (Azov, Myasnikovsky and Neklinovsky districts);;

4. State natural reserves ("Gornensky", "Levoberezhny")

5. 70 natural monuments with a total area of 20.47 thousand ha.

6. Local significance: 20 SPNA with a total area of 106.65 thousand hectares (Millerovsky, Oktyabrsky and Remontnensky districts and Taganrog city)

7. Territories with special protection regime: wetlands;14 key ornithological territories. The works on ecological carcass formation of the territories, adjoining to the nucleus Rostov-on-Don are increased today on the territory of Rostov agglomeration. Among the reasons of SPNAterritory boundaries alteration for the period of the last decade one can emphasize: intensification of anthropogenic load to the territory; alteration of land survey boundaries and land use methods; category alteration of landowners; exclusion of populated areas from the territories ofSPNA; alteration of functional zonation of the territory.All changes in the field of creating new and changing old boundaries of SPNA occur on the basis of regional environmental legislation:

1. The regional law of the Rostov region from 28.12.2005 No 434-3P"On Specially Protected Natural Territories of the Rostov Region".

2. The regional law of the Rostov region from 11.03.2003 No 316-3P"On Environmental Protection of the Rostov Region".

3. The regional law of the Rostov region dated 03.11.2006 No 578-3P "On Ecological Expertise in the Rostov Region". 
4. Government decree of the Rostov region from 01.12.2011 No 193 "About statement confirmation of order directing of the Rostov region Red Book".

5. Government decree of the Rostov region of May 15, 2014 No. 350 "On the approval of the organization and operation order of the Rostov region specially protected natural areas".

6. Government Decree of the Rostov region from 25.09.2-13 No. 595 "On approval of the Rostov region state program" Environmental protection and rational nature management".

7. Administration Decree of the Rostov region of 05.08.2003 No 358 "On the Rostov Region Red Book".

The ecological framework of the Rostov agglomeration is formed on scientifically grounded principles: ecological corridors (commutation), buffer zones, hierarchical cells, mosaic of territories of different scales and functions, relative ecological autonomy and discreteness of individual sites, historical trends in the development of the territory, individuality of naturalconditions of each territory region. The natural-ecological framework of the Rostov agglomeration territory is inextricably linked with the basin of the river. Don. In order to preserve and restore the natural landscapes of the left-bank floodplain of the river in 2015, by the decision of the Government of the Rostov Region, the state nature reserve "Levoberezhny" was established, the boundaries of which are within the territories of Rostov-on-Don. Previously, there was a state hunting reserve in these territories. The territory consists of 3 cluster sites with a total area of 1136.2155 hectares. According to the data of 2015, the habitat of roe deer European, deer spotted, white-tailed eagle, pheasants and partridges nest. 26 species of animals found on the territory of the reserve are listed in the Red Book of Russia, among them - 15 species of birds.

The territorial location of the reserve determines its strategic "transit" position for Eurasian migratory birds, as a nesting site and mass seasonal concentrations of waterfowl and waterbirds. A peculiarity of the anthropogenic impact on the natural complexes of the reserve is the neighborhood with the territories of large-scale construction of already existing and planned objects of economic activity on the considered section of the left-bank floodplain of the r. Don to the World Cup -2018. and a promising massive gathering of people in these places.Consequently, the territories of the reserve can become the sources of medical and environmental risks for the urban population and visitors of the city from the view point of the of natural-anthropurgic infections focuses formation associated with the arrival seasons(February-March, April-May) of migrants.An increase in the density of crow, waterbirds and waterfowl birds (common cormorants, grebes, herons, gulls, terns, ducks, geese, curlews, etc.) in the vicinity of the city will increase the risks of outbreaks of diseases such as tularemia, Crimean-Congo hemorrhagic fever (CCHF) and West Nile encephalitis (WNE)\% $[1,2,3]$. Contact of migrants with established synanthropic urban populations can lead to drift and seasonal rooting of arbovirus infections\% [4].Synanthropic species (roach, gray crow and common starling), blood-sucking mosquitoes - Cx. Pipiens, Ae. Vexans, Ae. Caspius, Ae. Cinereus, An. Claviger, An. Maculipennis, ixodid mites - N. m. Marginatum, R. rossicus and small mammals (an common vole, a mouse and a forest mouse) can increase the circulation of the West Nile encephalitis, the causative agent of tularemia and CCHF \%.

The comfort and security of the urban population of Rostov-on-Don, while preserving the existing ecological carcass of the territory, will depend on the eventsorganization to monitor species diversity and the number of epidemiologically significant faunal components as possible bearers and carriers of zoogenous infections.

\section{Лumepamypa}


1. Липкович А. Д., Орехов И. В., Адаменко В. И., Москвитина Э. А., Пичурина Н. Л.Курганчиковая мышь (MushortuianusNordman, 1840) в Ростовской области // Актуальные вопросы экологии и охраны природы экосистем южных регионов России и сопредельных территорий.Краснодар, 2001.

2. Липкович А. Д., Орехов И. В., Хохлов В. В., Стахеев В. В., Москвитина Э. А., Остроухова В. М., Пичурина Н. Л., Адаменко В. И., Водяницкая С. Ю., Феодоридис E. A. К характеристике синантропной фауны города Ростова-на-Дону // Актуальные вопросы экологии и охраны природы экосистем южных регионов России и сопредельных территорий. Краснодар, 2001.

3. Мишанькин Б. Н., Москвитина Э. А., Пичурина Н. Л., Романова Л. В., Сучков И. Ю., Орехов И. В., Хохлов В. В., Стахеев В. В., Федорук С. И. Туляремия: перспективы использования полимеразной цепной реакции при эпидемиологическом надзоре // Актуальные вопросы особо-опасных инфраструктур. Нальчик, 2000.

4. Онищенко Г. Г., Айдинов Г. Т., Москвитина Э. А., Ломов Ю. М., Тихонов Н. Г., Прометной В. И., Швагер М. М., Рыжков В. Ю., Савченко П. П., Дмитриева Т. А., Баташев В. В., Пухов Ю. М., Пичурина Н. Л., Иванова Н. Г., Гавринев С. А., Ковалев Е. В., Кипайкин В. А., Паук В. Л., Емельянова 3. Н., Орехов И. В., Липкович А. Д., Стахеев В. В., Трепель В. Г., Усаткин А. В., Марков В. И., Борисевич И. В., Меркулов В. А., Махлай А. А., Васильев Н. Т., Мишанькин Б. Н., Водопьянов С. О., Мазрухо Т. В., Бадуненко В. П. Крымская-Конго геморрагическая лихорадка в Ростовской области: эпидемиологические особенности вспышки // Журнал микробиологии. 2000. №2.

5. Орехов И. В., Родионов А. В., Налётов В. Г., Мишанькин Б. Н., Москвитнна Э. А., Пичурнна Н. Л., Романова Л. В. Фауна переносчиков как составная часть паразитарной системы природных очагов туляремии в Ростовской области // Природноочаговые инфекции в России: современная эпидемиология, диагностика, тактика защиты населения. Омск, 1998.

\section{References}

1. Lipkovich A.D., Orekhov I.V., Adamenko V.I., Moskvitina E.A., Pichurina N. L.Kurganchikovaya Mouse (Mus hortuianusNordman, 1840) in the Rostov Region // Topical questionsand environment conservancy of the ecosystems of the southern regions of Russia and the adjoining territories.Krasnodar, 2001.

2. Lipkovich A.D., Orekhov I.V., Khokhlov V.V., Stakheev V.V., Moskvitina E.A., Ostroukhova V.M., Pichurina N.L., Adamenko V.I., VodyanitskayaS.Yu., Feodoridis E.A. To the characteristic of the synanthropic fauna of Rostov-on-Don // Topical questions and environment conservancy of the ecosystems of the southern regions of Russia and the adjoining territories. Krasnodar, 2001.

3. Mishankin B.N., Moskvitina E.A., Pichurina N.L., Romanova L.V., Suchkov I. Yu., Orekhov I.V., Khokhlov V.V., Staheev V.V., Fedoruk S.I. Tularemia: Perspectives of the use of polymerase chain reaction in epidemiological surveillance// Topical questions of extremely-dangerous infrastructures.Nalchik, 2000.

4. Onishchenko G.G., Aidinov G.T., Moskvitina E.A., Lomov Yu. M., Tikhonov N.G., Prometnoy V.I., Shvager M.M., RyzhkovV.Yu., Savchenko P.P., Dmitrieva T.A., Batashev V.V., Pukhov Yu. M., Pichurina N.L., Ivanova N.G., Gavrinev S.A., KovalevE.V., Kipaikin V. A., Spider V.L., EmelyanovaZ. N., Orekhov I.V., Lipkovich A.D., Staheev V.V., Trepel V.G., Usatkin A.V., Markov V.I., Borisevich I.V., Merkulov V.A., Makhlai A.A., Vasilyev N.T., Mishankin B.N., Vodopyanov S.O., Mazruk- 
ho T.V., Badunenko V.P. Crimean-Congo Hemorrhagic fever in the Rostov region: epidemiological peculiarities of the outburst // Microbiology Journal. 2000.No2.

5. Orekhov I.V., Rodionov A.V., Naletov V.G., Mishankin B.N., Moskvitnna E.A., Pichurnna N.L., Romanova L.V. The carrier vector as an integral part of the parasitic system of natural foci ofTularemia in the Rostov Region // Natural Focal Infections in Russia: modernepidemiology, diagnostics, population protection tactics. Omsk, 1998. 